\title{
Gentian mosaic virus: A New Species in the Genus Fabavirus
}

\author{
Y. O. Kobayashi, A. Kobayashi, K. Hagiwara, H. Uga, Y. Mikoshiba, T. Naito, Y. Honda, and T. Omura
}

First, third, fifth, sixth, seventh, and eighth authors: National Agricultural Research Center, 3-1-1 Kan-nondai, Tsukuba, Ibaraki 305-8666, Japan; second author: National Agricultural Research Center for Hokkaido Region, Shinsei, Memuro, Hokkaido 082-0071, Japan; and fourth author: Saitama Agriculture and Forestry Research Center, 91 Rokumanbu, Kuki, Saitama 346-0037, Japan.

Current address of Y. O. Kobayashi: National Agricultural Research Center for Hokkaido Region, Shinsei, Memuro, Hokkaido 082-0071, Japan.

Current address of Y. Mikoshiba: National Institute of Livestock and Grassland Science, 768 Senbonmatsu, Nishinasuno, Nasu, Tochigi 3292793, Japan.

Current address of T. Naito: Okinawa Prefectural Agricultural Experiment Station, Horticultural Branch, 76 Kanekadan, Gushikawa, Okinawa 904-2241, Japan.

Accepted for publication 7 September 2004.

\begin{abstract}
Kobayashi, Y. O., Kobayashi, A., Hagiwara, K., Uga, H., Mikoshiba, Y., Naito, T., Honda, Y., and Omura, T. 2005. Gentian mosaic virus: A new species in the genus Fabavirus. Phytopathology 95:192-197.

A viral isolate, designated $\mathrm{N}-1$ and obtained from a gentian (Gentiana scabra) plant that exhibited mosaic symptoms, was transmitted mechanically to nine plant species in six families. These plants are known as hosts of fabaviruses. The N-1 isolate was composed of isometric particles $30 \mathrm{~nm}$ in diameter and included two RNA molecules of approximately 6.0 and $3.6 \mathrm{~kb}$ in length, as estimated by agarose gel electrophoresis. The RNAs were encapsidated separately in two of the three types of particle. Each particle contained two distinct proteins with $\mathrm{Mr}$ values of $39.3 \times$ $10^{3}$ and $26.6 \times 10^{3}$, as determined by sodium dodecyl sulfate-polyacrylamide gel electrophoresis. Analysis of complete nucleotide sequences of

the RNAs suggested that each encoded a single large polyprotein, in which putative functional proteins were arranged in a manner similar to those in Broad bean wilt virus 1 (BBWV-1) and Broad bean wilt virus 2 (BBWV-2), which are members of the genus Fabavirus (family Comoviridae). Analysis of the deduced amino acid sequences of the proteins indicated that those of isolate N-1 shared 38 to $66 \%$ identity with those of BBWV-1 and BBWV-2 but only 16 to $42 \%$ identity with those of a comovirus, Cowpea mosaic virus. Phylogenetic analysis, based on the amino acid sequences of RNA polymerase, placed isolate $\mathrm{N}-1$ in a separate lineage from BBWV-1 and BBWV-2. In indirect-enzyme-linked immunosorbent assay, isolate $\mathrm{N}-1$ exhibited distant serological relationship to BBWV-1, BBWV-2, and Lamium mild mosaic virus, another fabavirus. Our results suggest that N-1 represents a new species of Fabavirus. We propose the name Gentian mosaic virus for this new species.
\end{abstract}

Viruses in the genus Fabavirus (family Comoviridae) are transmitted by aphids in a nonpersistent manner and cause diseases in various vegetable and ornamental plants. Fabavirus particles are icosahedral, approximately $30 \mathrm{~nm}$ in diameter, and sediment as three components, designated $\mathrm{T}, \mathrm{M}$, and $\mathrm{B}$, during density gradient ultra-centrifugation (DGC) (26). The RNA genome consists of two single-stranded molecules of 6.0 to $6.3 \mathrm{~kb}$ (RNA-1) and 3.9 to $4.5 \mathrm{~kb}$ (RNA-2), which are separately encapsidated in the B and $\mathrm{M}$ components, respectively. Each of the three components is composed of two distinct proteins of $\mathrm{Mr} 40$ to $45 \times 10^{3}$ (large coat protein; LCP) and 21 to $27 \times 10^{3}$ (small coat protein; SCP).

Broad bean wilt virus 1 (BBWV-1) and Broad bean wilt virus 2 (BBWV-2), two distinct species in the genus Fabavirus, were differentiated by serology (24). In a previous study, we determined the complete nucleotide sequences of the RNAs of both BBWV-1 and BBWV-2 and reported the genetic relationship between the two viruses (8). Fabavirus RNAs are translated into single polyprotein precursors, from which functional proteins are derived by proteolytic cleavage, as also occurs in comoviruses, which are members of the same family (26). Sequence identity at the amino acid level among isolates of BBWV-2 was 87 to $96 \%$ for the polyprotein precursors and 73 to $98 \%$ for individual mature proteins

Corresponding author: Y. O. Kobayashi; E-mail address: oodaira@affrc.go.jp

DOI: 10.1094/PHYTO-95-0192

(C) 2005 The American Phytopathological Society
(8). In contrast, amino acid identity between isolates of BBWV-1 and BBWV-2 was only 55 to $61 \%$ (polyprotein precursors) and 39 to $67 \%$ (mature proteins).

Numerous fabavirus isolates have been obtained from various plants in Japan. Some of the isolates have been defined as BBWV-1 (DDBJ/EMBL/GenBank accession no. AB110537) or BBWV-2 $(6,9,11,15)$. However, most Japanese fabavirus isolates have not been classified. In our current studies of fabaviruses in Japan, we found an isolate with serological reactivities distinct from those of BBWV-1 and BBWV-2, and our observations suggested that we might have found a new species of Fabavirus. In this report, we show that the isolate represents a new fabavirus.

\section{MATERIALS AND METHODS}

Viral isolates. A fabavirus, designated $\mathrm{N}-1$, obtained from a gentian (Gentiana scabra) plant with mosaic symptoms, was provided by I. Fujisawa (National Agricultural Research Center, Ibaraki, Japan). Isolate PV132 of BBWV-1 and isolate PV131 of BBWV-2 were supplied by the American Type Culture Collection (Manassas, VA). Lamium mild mosaic virus (LMMV), which is another species in Fabavirus (26), was provided by R. G. Milne and M. Turina (Istituto di Virologia Vegetale del CNR, Tolino, Italy). Chenopodium quinoa plants were inoculated mechanically with each isolate for propagation.

Host range. Crude sap of $C$. quinoa leaves that had been infected with isolate $\mathrm{N}-1$ was inoculated mechanically to 21 plant 
species in nine families (Table 1). The experiment was conducted twice, and for each test approximately five plants of each species were inoculated and maintained in a greenhouse $\left(16\right.$ to $26^{\circ} \mathrm{C}$ under long day period) and monitored for up to 1 month for symptom development. Inoculated plants were assayed for viral infection by an enzyme-linked immunosorbent assay (ELISA).

Purification of viral particles and physicochemical properties. Most steps of the purification procedure were performed at $4^{\circ} \mathrm{C}$. N-1-infected leaves of $C$. quinoa were homogenized with Mcllvaine buffer $\left(0.1 \mathrm{M}\right.$ citric acid and $0.2 \mathrm{M} \mathrm{Na}_{2} \mathrm{HPO}_{4}$ were mixed to adjust to $\mathrm{pH} 7.0$ ) that contained $0.01 \mathrm{M} \mathrm{MgCl}_{2}, 10 \%$ (wt/vol) sucrose, and $0.2 \%(\mathrm{wt} / \mathrm{vol})$ sodium L-ascorbate. The homogenate was filtered through cotton cloth and clarified by blending for 2 min with $1 / 5$ volume of isoamyl alcohol and subsequent centrifugation at $18,500 \times g$ for $17 \mathrm{~min}$. The supernatant was allowed to stand on ice for $10 \mathrm{~min}$ and then centrifuged again. The aqueous phase was supplemented with Triton X-100, polyethylene glycol 6000, and $\mathrm{NaCl}$ to give final concentrations of $2 \%$ (vol/vol), $6 \%(\mathrm{wt} / \mathrm{vol})$, and $0.1 \mathrm{M}$, respectively. After stirring for $10 \mathrm{~min}$ at room temperature and incubation at $4{ }^{\circ} \mathrm{C}$ for $20 \mathrm{~min}$, the mixture was centrifuged at $12,096 \times g$ for $10 \mathrm{~min}$. The resultant pellet was resuspended in 1/10 volume of Mcllvaine buffer with the additives described previously, and the suspension was centrifuged at $31,000 \times g$ for $10 \mathrm{~min}$. The resultant supernatant was centrifuged on a cushion of $20 \%(\mathrm{wt} / \mathrm{vol})$ sucrose at $225,400 \times g$ for $1 \mathrm{~h}$. The resultant pellet was resuspended in Mcllvaine buffer $\left(\mathrm{pH} \mathrm{7.0)}\right.$ that contained $0.01 \mathrm{M} \mathrm{MgCl}_{2}$. After centrifugation at $6,000 \times g$ for $10 \mathrm{~min}$, the supernatant was subjected to DGC on a gradient of 10 to $40 \%$ (wt/vol) sucrose in the same solution at $190,400 \times g$ for $70 \mathrm{~min}$. The top (T), middle (M), and bottom (B) bands separated by DGC were collected separately and layered individually onto gradients of 40 to $60 \%$ (wt/vol) sucrose for a second DGC at 127,000 $\times g$ for $14 \mathrm{~h}$. Each re-formed band was then collected separately.

Purified viral particles were diluted fivefold with distilled water and visualized by electron microscopy (H-7000; Hitachi, Tokyo) after staining with $2 \%$ (wt/vol) uranyl acetate. Viral RNAs were extracted from purified virions using an RNaid Kit (Bio 101, La Jolla, CA) after treatment with $0.1 \%$ (wt/vol) proteinase $\mathrm{K}$ (Gibco, Rockville, MD). Viral RNAs were separated on a $0.8 \%$ (wt/vol) agarose gel prepared with $0.22 \mathrm{M}$ formaldehyde (20). Viral coat proteins (CPs) were separated from the purified virions by sodium dodecyl sulfate-polyacrylamide gel electrophoresis (SDS-PAGE) (12) on a $12.5 \%$ (wt/vol) polyacrylamide gel. Proteins were stained with $0.2 \%$ (wt/vol) Coomassie brilliant blue.

Cloning of viral genome. RNA- 1 of isolate N-1 was cloned by the same procedure used to clone RNA-1 of isolate PV132 (8). After reverse transcription-polymerase chain reaction (RT-PCR) using a $3^{\prime}$ rapid amplification of cDNA ends (RACE) system (Gibco) with the degenerate primer designated YGDDNL (8), cDNA was synthesized with the reverse primers N-1-135 (5'${ }^{4930}$ CACAATCAGCTAGTCTTCTAAAA $\left.{ }^{4908}-3^{\prime}\right)$ and N-1-0109L54 $\left(5^{\prime}-{ }^{3100}\right.$ ACCCTCTGTTTGGCATAAG $\left.{ }^{3082}-3^{\prime}\right)$. The 5'-terminal region was amplified by the $5^{\prime} \mathrm{RACE}$ method (2) with nested reverse primers $\mathrm{N}-1-100 \mathrm{~L}\left(5^{\prime}-{ }^{131}\right.$ GCTGTTTAAGAAGGCGTTTC $\left.^{112}-3^{\prime}\right)$ and N-1-20L ( $5^{\prime}-{ }^{54}$ ACCGAAAGCTGTTTTAGTA$\left.\mathrm{AC}^{34}-3^{\prime}\right)$.

For analysis of N-1 RNA-2, total RNA was extracted from N-1infected $C$. quinoa leaves with an RNeasy Plant Mini Kit (Qiagen, Hilden, Germany) and used as template for amplification of $3^{\prime}-$ terminal region of RNA-2. RT-PCR was performed with the degenerate primer IP-1885dU (8) and the $3^{\prime}$ RACE system. Amplified cDNA products were separated by electrophoresis on a $1 \%$ agarose gel. Putative cDNA products from N-1 RNA-2 purified with a QIAquick Gel Extraction Kit (Qiagen) were cloned into the pGEM-T Easy Vector (Promega, Madison, WI), and three clones were sequenced. RNA-2 was extracted from the purified virions of isolate $\mathrm{N}-1$ using the RNeasy Plant Mini Kit after treat- ment with $0.1 \%(\mathrm{wt} / \mathrm{vol})$ proteinase $\mathrm{K}$ and used as templates for subsequent cDNA amplification. After single-stranded cDNA was synthesized with the reverse primer N-1-411L $\left(5^{\prime}-{ }^{3003}\right.$ ACTTGCTCCCATGATAACC ${ }^{2985}-3^{\prime}$ ) using Superscript II $\mathrm{RNaseH}^{-}$ Reverse Transcriptase (Gibco), double-stranded cDNA was amplified by PCR with the reverse primer N-1-38L (5'- ${ }^{1859}$ CACCAATCACAGCACGAGAA $\left.{ }^{1840}-3^{\prime}\right)$ and the forward degenerate primer IP-1276dU $\left(5^{\prime}{ }^{1189} \mathrm{~T}(\mathrm{~A} / \mathrm{T})(\mathrm{C} / \mathrm{T}) \mathrm{CCI}(\mathrm{A} / \mathrm{G}) \mathrm{A}(\mathrm{A} / \mathrm{G}) \mathrm{GTIAA}-\right.$ $\left.(\mathrm{C} / \mathrm{T})(\mathrm{C} / \mathrm{T}) \mathrm{TIGA}(\mathrm{C} / \mathrm{T}) \mathrm{AA}(\mathrm{C} / \mathrm{T}) \mathrm{TA}^{1214}-3^{\prime}\right)$ that was based on the highly conserved amino acid sequence ${ }^{336}(\mathrm{~F} / \mathrm{Y}) \mathrm{P}(\mathrm{E} / \mathrm{K}) \mathrm{VNLD}-$ $\mathrm{NY}^{344}$ of the N-terminal proteins of two isolates of BBWV-1 (PV132 and PV176) and seven isolates of BBWV-2 (E, IP, L, MB7, PatMMV, PV131, and 1-2). Amplified cDNA products were cloned into the pGEM-T Easy Vector, and three clones were sequenced. The 5'-terminal region of RNA-2 was amplified by the 5'RACE method with universal primers (4) and reverse primer N1-200L ( $5^{\prime}-{ }^{1433}$ TAGTCTTCAGCATCTTCATC $\left.{ }^{1414}-3^{\prime}\right)$. Amplified cDNA products were cloned into the pGEM-T vector (Promega), and five clones were sequenced.

Sequence analysis. Sequence data were compiled and analyzed with GENETYX-MAC programs (Software Development Co., Ltd., Tokyo). The sequence of isolate N-1 was compared with those of all isolates of BBWV-1 and BBWV-2 and a comovirus, Cowpea mosaic virus (CPMV), which are available in the DDBJ/EMBL/GenBank databases.

Phylogenetic analysis was performed to determine the relationship of isolate N-1 with fabaviruses, comoviruses, and nepoviruses, which are members of three genera in the family Comoviridae (26). A phylogenetic tree was generated from the deduced amino acid sequences of RNA-dependent RNA polymerases (RdRp) by the neighbor-joining algorithm with ClustalX programs (23). The data set was subjected to 100 bootstrap replicates. Satsuma dwarf virus, which was tentatively designated as a nepovirus and more recently placed in a putative new family because of its unique genome features (7), was used as the outgroup.

ELISA. Antiserum against isolate $\mathrm{N}-1$ was raised in a rabbit immunized with virions (approximately $0.5 \mathrm{mg}$ ) by intravenous injection followed by intramuscular injection 1 week later with

TABLE 1. Experimental host range of Gentian mosaic virus and symptoms of infected plants

\begin{tabular}{|c|c|c|}
\hline Family & Species & Symptoms ${ }^{\mathrm{a}}$ \\
\hline Aizoaceae & Tetragonia tetragonoides & (CS), NS or RS/- \\
\hline Amaranthaceae & Gomphrena globasa & $(\mathrm{CS}) / \mathrm{CS}, \mathrm{M}, \mathrm{Mal}$ \\
\hline Asteraceae & Lactuca sativa & $-1-$ \\
\hline Brassicaceae & $\begin{array}{l}\text { Brassica rapa var. glabra } \\
\text { Raphanus sativus }\end{array}$ & $\begin{array}{l}-1- \\
-1-\end{array}$ \\
\hline Chenopodiaceae & $\begin{array}{l}\text { Beta vulgaris var. vulgaris } \\
\text { Chenopodium amaranticolor } \\
\text { Chenopodium quinoa } \\
\text { Spinacia oleracea }\end{array}$ & $\begin{array}{l}\text { (CS), NS/- } \\
\text { CS/- } \\
\text { CS/CS, (Mal) } \\
(\mathrm{CS}), \mathrm{NS},(\mathrm{N}) / \\
\quad(\mathrm{M}), \mathrm{N}, \mathrm{Mal}\end{array}$ \\
\hline Cucurbitaceae & $\begin{array}{l}\text { Cucumis sativus } \\
\text { Cucurbita moschata }\end{array}$ & $\begin{array}{l}-1- \\
-1-\end{array}$ \\
\hline Fabaceae & $\begin{array}{l}\text { Vicia faba } \\
\text { Vigna unguiculata var. unguiculata }\end{array}$ & $\begin{array}{l}(\mathrm{NS}, \mathrm{N}) / \mathrm{N} \\
-/-\end{array}$ \\
\hline Gentianaceae & Gentiana scabra var. buergeri & $+/ \mathrm{M}$ \\
\hline Solanaceae & $\begin{array}{l}\text { Capsicum anпиит } \\
\text { Datura stramonium } \\
\text { Nicotiana benthamiana } \\
\text { Nicotiana glutinosa } \\
\text { Nicotiana tabacum } \text { cv. Bright Yellow } \\
\text { Nicotiana tabacum cv. White Burley } \\
\text { Petunia } \times \text { hybrida } \\
\text { Physalis floridana }\end{array}$ & $\begin{array}{l}-1- \\
-/- \\
-/ \mathrm{M} \\
-1- \\
-1- \\
-1- \\
-1- \\
-/-\end{array}$ \\
\hline
\end{tabular}

a Symptoms on inoculated leaves and on upper uninoculated leaves are denoted to the left and right of the slash (/), respectively. CS, chlorotic spots; NS, necrotic spots; RS, ring spots; -, no infection; M, mosaic; Mal, malformation; N, necrosis; and +, symptomless latent infection. Parentheses indicate occasional appearance. 
virions (approximately $0.5 \mathrm{mg}$ ) that had been emulsified with an equal volume of Freund's complete adjuvant. One month after the second injection, the rabbit was given two intravenous injections (approximately $0.3 \mathrm{mg}$ of virions per injection) at intervals of 1 week. The rabbit was bled 1 week after the fourth injection. Preparation of antiserum against PV132 was described previously (8), and antiserum against PV131 was prepared by the same procedure as that used to prepare the antiserum against PV132. Antiserum against LMMV was provided by R. G. Milne and M. Turina.

Antisera incubated with extracts of noninoculated leaves of C. quinoa were used for the non-precoated indirect-ELISA that was performed as described by Takeuchi et al. (21) with some modifications. Each leaf sample was macerated in phosphatebuffered saline $(\mathrm{pH} 7.5)$ and crude sap was subjected to a series of 10 -fold dilutions up to $10^{-4}$. Diluted samples were placed in duplicate wells.

\section{RESULTS}

Host range. Isolate N-1 successfully infected a variety of plant species in six families: Aizoaceae, Amaranthaceae, Chenopodiaceae, Fabaceae, Gentianaceae, and Solanaceae (Table 1). Thus, the $\mathrm{N}-1$ host range resembled those of fabaviruses $(14,16,22)$. However, N-1 only induced localized symptoms on $C$. amaranticolor, which exhibits systemic symptoms upon infection with other fabaviruses. Furthermore, the N-1 isolate produced symptoms only on Nicotiana benthamiana among a variety of solanaceous plants that frequently react to fabavirus infection. Gentian plants infected with the N-1 isolate developed mosaic systemic symptoms.

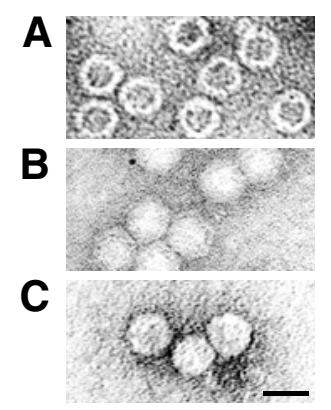

Fig. 1. Electron micrographs of purified particles of Gentian mosaic virus after staining with $2 \%$ uranyl acetate. A, T component (empty particles); B, M component (intact particles); and $\mathbf{C}, \mathbf{B}$ component (intact particles). Bar = $30 \mathrm{~nm}$.

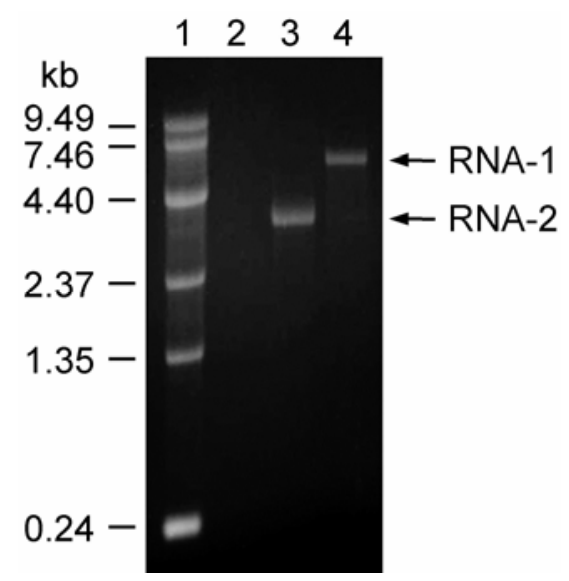

Fig. 2. Electrophoresis on a $0.8 \%(\mathrm{wt} / \mathrm{vol})$ denaturing agarose gel of viral RNAs extracted from the T (lane 2), M (lane 3), and B (lane 4) components of Gentian mosaic virus. Lane 1, Single-stranded RNA markers (Gibco, Rockville, MD).
Physicochemical properties of purified viral particles. Purified particles of isolate $\mathrm{N}-1$ were separated as three components, corresponding to T, M, and B (26), and collected separately from the three bands that formed during DGC. Electron microscopy revealed that each of the three components contained isometric particles of approximately $30 \mathrm{~nm}$ in diameter. The $\mathrm{T}$ component consisted of empty particles, while the $\mathrm{M}$ and $\mathrm{B}$ components included mostly intact particles (Fig. 1). Electrophoresis on an agarose gel under denaturing conditions revealed that the $\mathrm{T}$ component contained no RNA, while the $\mathrm{M}$ and $\mathrm{B}$ components contained an RNA of $3.57 \mathrm{~kb}$ (RNA-2) and an RNA of $5.99 \mathrm{~kb}$ (RNA-1), respectively (Fig. 2). Each of the three components contained two CPs, corresponding to LCP and SCP (26), with Mr values of $39.3 \times 10^{3}$ and $26.6 \times 10^{3}$, respectively, as determined by SDS-PAGE (Fig. 3 ).

Characterization of the genome. The complete nucleotide sequence of RNA-1 from isolate N-1 consisted of 5,836 nucleotides (accession no. AB084452). The RNA appeared to contain a single, long open reading frame (ORF) with an initiation codon at positions 175 through 177 and a termination codon (UGA) at positions 5734 through 5736. The 5' nontranslated region (NTR) of the molecule contained the repeated motif AAACAGCUUUC (18) from positions 23 to 33,41 to 51,85 to 95 , and 125 to 135 ,

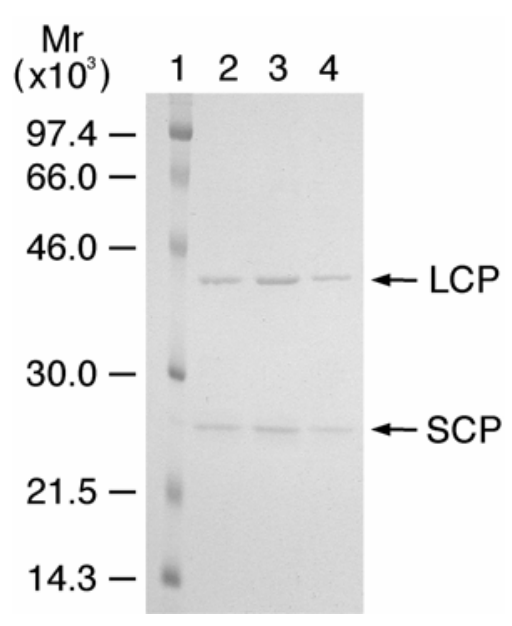

Fig. 3. Fractionation by sodium dodecyl sulfate-polyacrylamide gel electrophoresis on a $12.5 \%(\mathrm{wt} / \mathrm{vol})$ gel of coat proteins from the T (lane 2), M (lane 3 ), and B (lane 4) components of Gentian mosaic virus, after staining with Coomassie brilliant blue. Lane 1, molecular mass markers (Amersham, Little Chalfont, UK). LCP, large coat protein; and SCP, small coat protein.

RNA-1

\begin{tabular}{|c|c|c|c|}
\hline $\mathrm{GQ}$ ! & \multicolumn{3}{|c|}{$\mathrm{AQ} / \mathrm{S}, \mathrm{GQ} / \mathrm{A}, \mathrm{GQ} / \mathrm{S}$} \\
\hline Co-pro & Hel? & Pro & RdRp \\
\hline $35 \mathrm{kDa}$ & $66 \mathrm{kDa}$ & $3 \mathrm{kD}$ & $79 \mathrm{kDa}$ \\
\hline
\end{tabular}

RNA-2

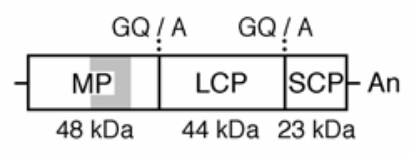

\begin{tabular}{lllll|l|l}
\hline & 1 & 1 & 1 & & \\
0 & 1 & 2 & 3 & 4 & 5 & 6
\end{tabular}

Fig. 4. Genome organization of Gentian mosaic virus. Short horizontal lines and large rectangles represent noncoding sequences and long open reading frames, respectively. Vertical lines through the long rectangles indicate putative sites of polyprotein cleavage. Calculated values of $\mathrm{Mr}$ and positions of mature proteins are indicated. Co-pro, cofactor required for the proteinase; Hel, putative helicase; VPg, genome-linked protein; Pro, proteinase; RdRp, RNA-dependent RNA polymerase; MP, movement protein; LCP, large coat protein; and SCP, small coat protein. Conserved motifs in each protein are indicated by shading. 
and the $3^{\prime} \mathrm{NTR}$ was followed by a poly(A) tail, as do RNA-1 and RNA-2 of BBWV-1 and BBWV-2 (8).

The complete nucleotide sequence of RNA-2 from isolate $\mathrm{N}-1$ consisted of 3,372 nucleotides (accession no. AB084453) and contained a single long ORF, which initiated at positions 184 through 186 and terminated with a UGA codon at positions 3244 through 3246 . The $5^{\prime} \mathrm{NTR}$ contained the same repeated motif as that found in RNA-1 at positions 22 through 32, 61 through 71, and 91 through 101, and the $3^{\prime}$ NTR was followed by a poly(A) tail.

The 5'NTRs of RNA-1 and RNA-2 of N-1 were only $60 \%$ identical to one another. In contrast, high identity was apparent when we compared only the 35 nucleotides at each $5^{\prime}$ end, in which 33 nucleotides were identical. This conserved sequence resembled that conserved among RNAs of BBWV-1 and BBWV-2 (8). Moreover, the first 23 nucleotides of RNA-1 and the first 21 nucleotides of RNA-2 may form a stem/loop structure similar to hairpin I, which was reported to be important for replication of the comovirus, CPMV (3). The $5^{\prime}$ nucleotides of the RNAs of BBWV-1 and BBWV-2 also may form a similar structure (8).

The 3'NTRs of RNA-1 and RNA-2 of N-1 were $67 \%$ identical, with relatively conserved sequence in the last 83 nucleotides, in which 68 nucleotides were identical. The consensus sequence TAGT or TATGT, which plays a role in the termination of tran- scription of some genes and in the polyadenylation of their transcripts in yeast (27), was found 97 to 93 and 80 to 77 nucleotides upstream of the poly(A) tail in RNA-1 and 80 to 77 and 14 to 10 nucleotides upstream of the poly(A) tail in RNA-2, as also is the case for BBWV-1 and BBWV-2 (8). In contrast, the polyadenylation signal for most eukaryotic mRNAs, AAUAAA (17), was found 66 to 61 nucleotides upstream of the poly(A) tail in both RNA-1 and RNA-2 of N-1. The signal sequence was found in the 3'NTR of BBWV-1 and BBWV-2 RNA-2, with an adjacent conserved sequence of 45 nucleotides. However, both molecules of $\mathrm{N}-1$ have the signal sequence without the adjacent conserved sequence.

The RNA-1 of N-1 encoded a polyprotein of 1,853 amino acids with a calculated $\mathrm{Mr}$ of 206,708. Putative sites of proteolytic cleavage were identified at the $\mathrm{Q} / \mathrm{F}, \mathrm{Q} / \mathrm{S}, \mathrm{Q} / \mathrm{A}$, and $\mathrm{Q} / \mathrm{S}$ dipeptides at positions 323/324, 914/915, 940/941, and 1149/1150, respectively, in the polyprotein (Fig. 4), on the basis of a comparison with the corresponding sites in the polyprotein of CPMV. These sites in the polyprotein of $\mathrm{N}-1$ had a glycine residue at the -2 position, resembling those in polyproteins encoded by RNA-1 and RNA-2 of isolates of BBWV-1 and BBWV-2, with the exception of the second site (914/915), in which alanine was found before the dipeptide, as occurs in the RNA-1-encoded protein of isolate

TABLE 2. Nucleotide and amino acid sequence identity of RNA-1 between Gentian mosaic virus and select viruses of the family Comoviridae

\begin{tabular}{|c|c|c|c|c|c|c|c|c|c|c|c|}
\hline \multirow[b]{3}{*}{ Genus } & \multirow[b]{3}{*}{ Species } & \multirow[b]{3}{*}{ Isolate } & \multirow{3}{*}{$\begin{array}{c}\text { Accession } \\
\text { no. }\end{array}$} & \multicolumn{8}{|c|}{ Sequence identity (\%) } \\
\hline & & & & \multicolumn{2}{|c|}{ Nucleotide $^{\mathrm{a}}$} & \multicolumn{6}{|c|}{ Amino acid ${ }^{b}$} \\
\hline & & & & 5'NTR & 3'NTR & Poly & Co-pro & Hel & VPg & Pro & $\mathrm{RdRp}$ \\
\hline \multirow[t]{8}{*}{ Fabavirus } & Broad bean wilt virus 1 & PV132 & AB084450 & 56 & 50 & 59 & 42 & 64 & 65 & 53 & 64 \\
\hline & Broad bean wilt virus 2 & B935 & AF149425 & 59 & 55 & 59 & 39 & 64 & 54 & 53 & 66 \\
\hline & & IA & AB051386 & 57 & 57 & 59 & 39 & 63 & 54 & 54 & 66 \\
\hline & & IP & $\mathrm{AB} 023484$ & 58 & 55 & 59 & 39 & 63 & 46 & 56 & 65 \\
\hline & & Korea & AF144234 & $-\mathrm{c}$ & 55 & - & - & 64 & 54 & 54 & 66 \\
\hline & & MB7 & $\mathrm{AB} 013615$ & 57 & 54 & 58 & 38 & 63 & 59 & 55 & 66 \\
\hline & & $\mathrm{ME}$ & AF225953 & 58 & 56 & 58 & 39 & 63 & 46 & 55 & 65 \\
\hline & & PatMMV & AB050782 & 57 & 54 & 59 & 38 & 63 & 54 & 55 & 66 \\
\hline Comovirus & Cowpea mosaic virus & & X00206 & 50 & 47 & 33 & 20 & 31 & 29 & 31 & 42 \\
\hline
\end{tabular}

a NTR, nontranslated region.

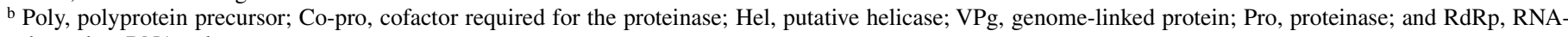
dependent RNA polymerase.

c Sequence data are not available.

TABLE 3. Nucleotide and amino acid sequence identity of RNA-2 between Gentian mosaic virus and select viruses of the family Comoviridae

\begin{tabular}{|c|c|c|c|c|c|c|c|c|c|}
\hline \multirow[b]{3}{*}{ Genus } & \multirow[b]{3}{*}{ Species } & \multirow[b]{3}{*}{ Isolate } & \multirow{3}{*}{$\begin{array}{c}\text { Accession } \\
\text { no. }\end{array}$} & \multicolumn{6}{|c|}{ Sequence identity (\%) } \\
\hline & & & & \multicolumn{2}{|c|}{ Nucleotide $^{a}$} & \multicolumn{4}{|c|}{ Amino acid ${ }^{b}$} \\
\hline & & & & 5'NTR & 3'NTR & Poly & MP & LCP & SCP \\
\hline \multirow[t]{17}{*}{ Fabavirus } & Broad bean wilt virus 1 & Delphinium & AB110537 & $-{ }^{c}$ & - & - & - & 63 & 62 \\
\hline & & PV132 & $\mathrm{AB} 084451$ & 53 & 48 & 58 & 51 & 64 & 62 \\
\hline & & PV176 & AB018703 & - & 45 & - & - & 64 & 59 \\
\hline & & Singapore & AF225955 & 53 & 45 & 58 & 50 & 64 & 59 \\
\hline & Broad bean wilt virus 2 & B935 & AJ132844 & 56 & 48 & 55 & 48 & 61 & 58 \\
\hline & & $\mathrm{E}$ & AB018699 & - & 48 & - & - & 62 & 59 \\
\hline & & IA & AB032403 & 58 & 46 & 55 & 48 & 62 & 59 \\
\hline & & IP & AB018698 & 62 & 47 & 55 & 49 & 62 & 57 \\
\hline & & Korea K & AF104335 & - & 46 & - & - & 61 & 58 \\
\hline & & $\mathrm{L}$ & AB018700 & - & 46 & - & - & 61 & 59 \\
\hline & & MB7 & AB013616 & 60 & 49 & 55 & 49 & 61 & 59 \\
\hline & & $\mathrm{ME}$ & AF225954 & 60 & 42 & 55 & 48 & 61 & 58 \\
\hline & & PatMMV & AB011007 & 58 & 46 & 54 & 49 & 56 & 60 \\
\hline & & PV131 & U65985 & - & - & - & - & 61 & - \\
\hline & & P158 & AF228423 & 56 & 49 & 55 & 47 & 62 & 59 \\
\hline & & South Korea & AF316363 & - & - & - & - & - & 60 \\
\hline & & $1-2$ & AB018701 & - & 45 & - & 47 & 61 & 58 \\
\hline Comovirus & Cowpea mosaic virus & & X00729 & 50 & 47 & 20 & 21 & 20 & 16 \\
\hline
\end{tabular}

a NTR, nontranslated region.

b Poly, polyprotein precursor; MP, movement protein; LCP, large coat protein; and SCP, small coat protein.

c Sequence data are not available. 
PV132 of BBWV-1 (8). The putative motifs specific for proteinase cofactor (19), helicase (10), genome-linked protein (18), proteinase (10), and $\operatorname{RdRp}(10)$ all were present in the polyprotein encoded by RNA-1 at positions 183 to 256,483 to 591, 915 to 940, 974 to 1127 , and 1428 to 1540 (Fig. 4), supporting the prediction that RNA-1 of N-1 encodes functional proteins in a similar manner to the corresponding RNAs of BBWV-1, BBWV-2 (8), and a comovirus, CPMV (26).

The RNA-2 of N-1 encoded a polyprotein of 1,020 amino acids with a calculated $\mathrm{Mr}$ of 114,650 . Comparison with a polyprotein encoded by RNA-2 from isolate IP of BBWV-2, which contains two CPs in the C-terminal region (8), suggested putative sites of cleavage at the Q/A dipeptides at positions 421/422 and 823/824 in the polyprotein of $\mathrm{N}-1$ (Fig. 4). These sites have a glycine residue at the -2 position. The putative motif specific for movement protein (1) was found in the N-terminal region at positions 197 through 329, as is the case for BBWV-1, BBWV-2 (8), and CPMV (26).

Amino acid sequence identity between N-1 and BBWV-1 ranged from 58 to $59 \%$ for the polyprotein precursor and from 42 to $65 \%$ for individual mature proteins (Tables 2 and 3 ). The corresponding values for $\mathrm{N}-1$ and BBWV-2 were from 54 to $59 \%$ (polyprotein) and from 38 to $66 \%$ (mature proteins).

In a phylogenetic analysis based on amino acid sequences of the RdRp, isolate $\mathrm{N}-1$ grouped with members of the genus Fabavirus (Fig. 5). In the fabavirus group, isolate N-1 diverged from a node basal to that shared by BBWV-1 and BBWV-2.

Serology. Isolate N-1 was detected only weakly, or not at all, by indirect-ELISAs performed with antisera raised against PV132 (BBWV-1), PV131 (BBWV-2), and LMMV (Table 4). As with the other fabavirus antisera, the antiserum against $\mathrm{N}-1$ reacted strongly with the homologous antigen and weakly or not at all with heterologous antigens from different species in Fabavirus.

\section{DISCUSSION}

Physiochemical properties of $\mathrm{N}-1$ virions were similar to those of both fabaviruses and comoviruses. However, biological properties of N-1 were more similar to fabaviruses than to comoviruses. Comoviruses tend to have narrow host ranges (25). In contrast, $\mathrm{N}-1$ was easily transmitted via infected sap to plants in six families, with a host range similar (but not identical) to those of fabaviruses.

The genome organization of isolate $\mathrm{N}-1$ was similar to that of BBWV-1, BBWV-2 (8), and a comovirus, CPMV (26). The low amino acid sequence identity of proteins encoded by the RNAs of $\mathrm{N}-1$ to those of CPMV (16 to $42 \%$; Tables 2 and 3) suggests that $\mathrm{N}-1$ is not a comovirus. In addition to BBWV-1 and BBWV-2, LMMV and Patchouli mild mosaic virus (PatMMV) have been

TABLE 4. Serological relationships among Gentian mosaic virus and three species in the genus Fabavirus, as determined by indirect enzyme-linked immunosorbent assays (ELISA)

\begin{tabular}{llllllll}
\hline \multicolumn{3}{c}{ Antisera against } & & & \multicolumn{4}{c}{ Results of ELISA $^{\mathrm{a}}$} \\
\cline { 1 - 2 } \cline { 5 - 7 } Species & Isolate & & N-1 & PV132 & PV131 & LMMV \\
\hline Gentian mosaic virus & N-1 & & +++ & + & - & - \\
Broad bean wilt virus 1 & PV132 & & + & +++ & - & - \\
Broad bean wilt virus 2 & PV131 & & - & + & +++ & - \\
Lamium mild mosaic virus & & & - & - & - & +++ \\
\hline
\end{tabular}

a Values for 100-fold diluted sample of leaf sap are shown. Absorbance at $415 \mathrm{~nm}:+++$, more than $2.0 ;+, 0.3$ to 0.6 ; and - , less than 0.3 .

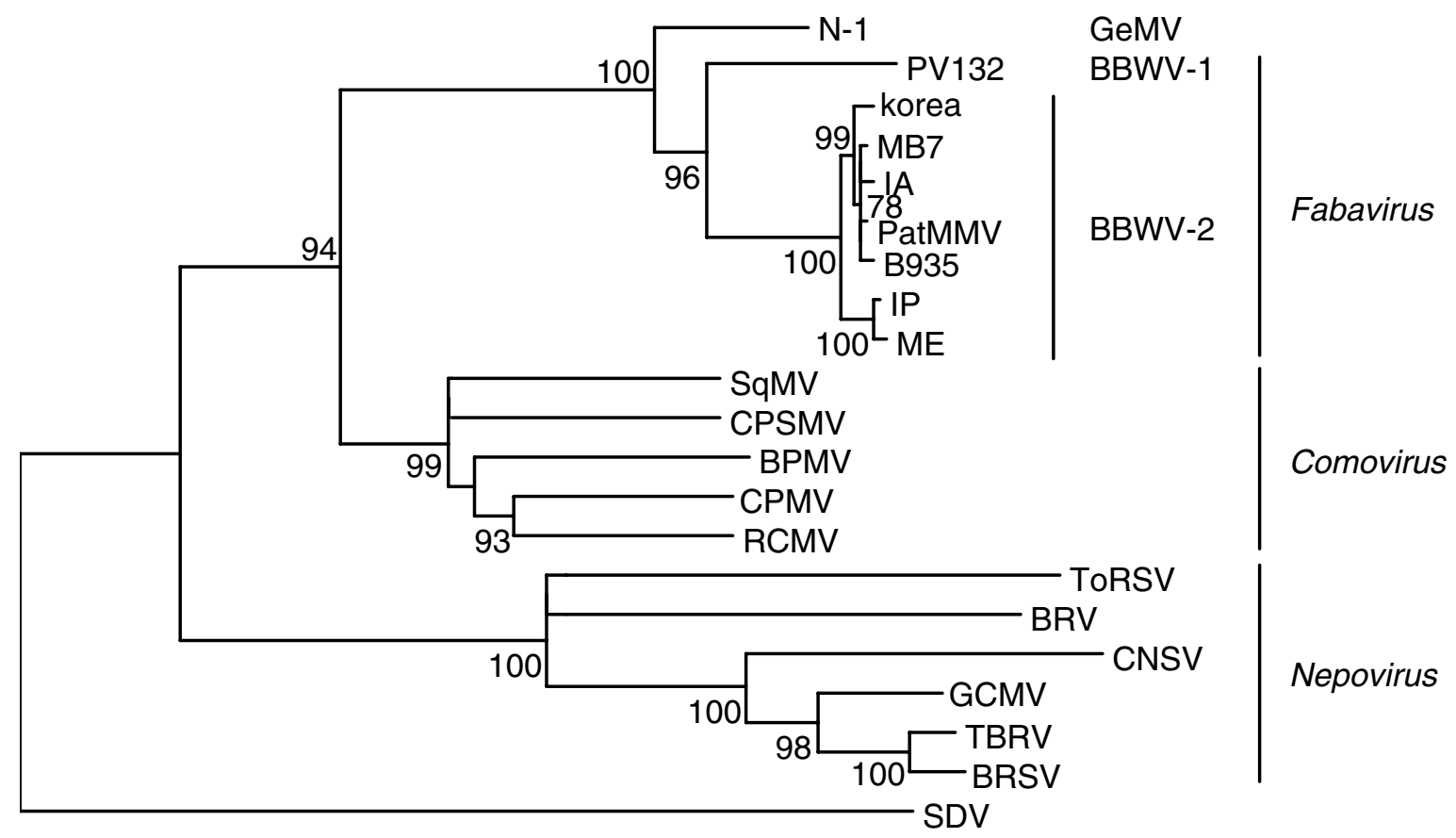

\footnotetext{
0.1

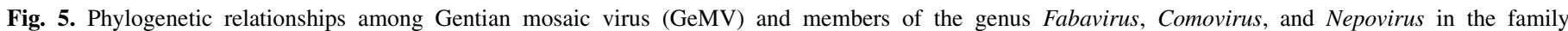

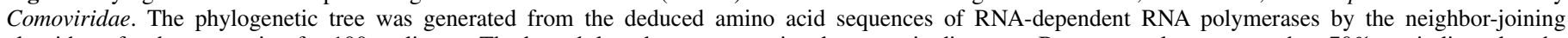

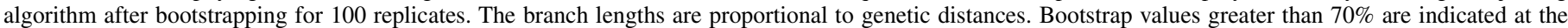

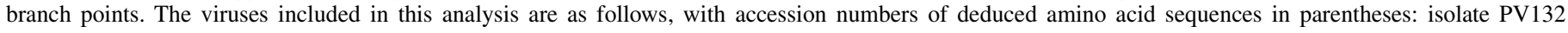

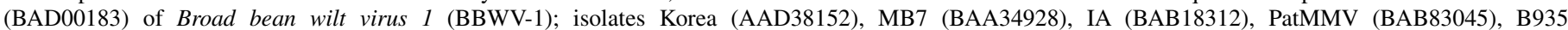

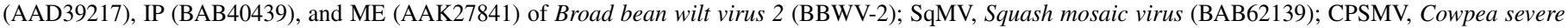

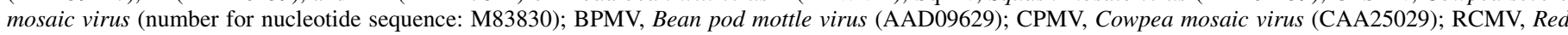

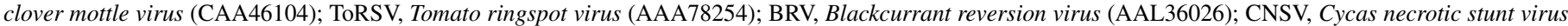

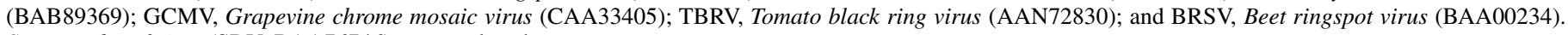
Satsuma dwarf virus (SDV; BAA76746) was used as the outgroup.
} 
classified as species of Fabavirus (26). However, recent sequence analysis of PatMMV suggested that it might be synonymous to BBWV-2 $(5,6)$. No sequence data are available for LMMV. The proteins of $\mathrm{N}-1$ exhibited limited identity to those of BBWV-1 (42 to $65 \%$ ) and to those of BBWV-2 (38 to 66\%). The extent of such identity, which was similar to that between proteins of BBWV-1 and BBWV-2 (8), and the results of phylogenetic analysis of the RdRp clearly indicate that isolate $\mathrm{N}-1$ should be a viral species distinct from BBWV-1 and BBWV-2.

One criterion of viral taxonomy is serological relationships. The serological reactivities among N-1, BBWV-1, BBWV-2, and LMMV, as measured by the absorbance in ELISA, clearly showed that only homologous combinations of antigen and the antiserum showed strong reactions. The reactions were very weak or negligible among heterologous combinations. These results suggest that N-1 and LMMV are distinct viruses, and also demonstrate that $\mathrm{N}-1$ should be classified as a new species in the genus Fabavirus. We propose the name Gentian mosaic virus (GeMV) for this new species.

In our recent studies of fabaviruses in Japan, we revealed that BBWV-2 was prevalent in Japan. GeMV has been detected only in gentian plants in limited areas in the field. However, experimental data indicate that $\mathrm{N}-1$ can infect several commercial crops, such as spinach (Spinacia oleracea), that has been reported to suffer serious damage upon infection by fabaviruses (13). N-1 also was able to infect broad bean (Vicia fava), a common host of fabaviruses in China and Japan. Thus, it is possible that GeMV also may occur in the hosts. The antiserum against GeMV prepared in this study will help us to identify the new virus more rapidly in the field.

\section{ACKNOWLEDGMENTS}

We thank I. Fujisawa for supplying a viral isolate and for helpful suggestions; R. G. Milne and M. Turina for supplying a viral isolate and an antiserum; K. T. Natsuaki of the Tokyo University of Agriculture and K. Yamashita of Aomori Green Bio Center for helpful suggestions; and H. Hibino of the International Rice Research Institute (Japan Office, Ibaraki) for critical reading of the manuscript.

\section{LITERATURE CITED}

1. Chen, X., and Bruening, G. 1992. Nucleotide sequence and genetic map of Cowpea severe mosaic virus RNA 2 and comparisons with RNA 2 of other comoviruses. Virology 187:682-692.

2. Chen, Z. 1996. Simple modifications to increase specificity of the 5'RACE procedure. Trends Genet. 12:87-88.

3. Goldbach, R. W., and Wellink, J. 1996. Comoviruses: Molecular biology and replication. Pages 35-76 in: The Plant Viruses, volume 5. Polyhedral Virions and Bipartite RNA Genomes. B. D. Harrison and A. F. Murant, eds. Plenum Press, New York.

4. Hagiwara, K., and Matsumoto, T. 2000. Nucleotide sequences of genome segments 6 and 7 of Bombyx mori cypovirus 1, encoding the viral structural proteins V4 and V5, respectively. J. Gen. Virol. 81:1143-1147.

5. Ikegami, M., Kawashima, H., Natsuaki, T., and Sugimura, N. 1998. Complete nucleotide sequence of the genome organization of RNA2 of Patchouli mild mosaic virus, a new fabavirus. Arch. Virol. 143:24312434.

6. Ikegami, M., Onobori, Y., Sugimura, N., and Natsuaki, T. 2001. Complete nucleotide sequence and the genome organization of Patchouli mild mosaic virus RNA1. Intervirology 44:355-358.
7. Iwanami, T., Kondo, Y., and Karasev, A. V. 1999. Nucleotide sequences and taxonomy of Satsuma dwarf virus. J. Gen. Virol. 80:793-797.

8. Kobayashi, Y. O., Kobayashi, A., Nakano, M., Hagiwara, K., Honda, Y., and Omura, T. 2003. Analysis of genetic relationships between Broad bean wilt virus 1 and Broad bean wilt virus 2. J. Gen. Plant Pathol. 69:320-326.

9. Kobayashi, Y. O., Nakano, M., Kashiwazaki, S., Naito, T., Mikoshiba, Y., Shiota, A., Kameya-Iwaki, M., and Honda, Y. 1999. Sequence analysis of RNA-2 of different isolates of Broad bean wilt virus confirms the existence of two distinct species. Arch. Virol. 144:1429-1438.

10. Koonin, E. V., and Dolja, V. V. 1993. Evolution and taxonomy of positivestrand RNA viruses: Implications of comparative analysis of amino acid sequences. Crit. Rev. Biochem. Mol. Biol. 28:375-430.

11. Kuroda, T., Okumura, A., Takeda, I., Miura, Y., and Suzuki, K. 2000. Nucleotide sequence and synthesis of infectious RNA from cloned cDNA of Broad bean wilt virus 2 RNA 2. Arch. Virol. 145:787-793.

12. Laemmli, U. K. 1970. Cleavage of structural proteins during the assembly of the head of bacteriophage T4. Nature 227:680-685.

13. Lisa, V., and Boccardo, G. 1996. Fabaviruses: Broad bean wilt and allied viruses. Pages 229-250 in: The Plant Viruses, volume 5. Polyhedral Virions and Bipartite RNA Genomes. B. D. Harrison and A. F. Murant, eds. Plenum Press, New York.

14. Lisa, V., Luisoni, E., Boccardo, G., Milne, R. G., and Lovisolo, O. 1982. Lamium mild mosaic virus: A virus distantly related to broad bean wilt. Ann. Appl. Biol. 100:467-476.

15. Nakamura, S., Iwai, T., and Honkura, R. 1998. Complete nucleotide sequence and genome organization of Broad bean wilt virus 2. Ann. Phytopathol. Soc. Jpn. 64:565-568.

16. Natsuaki, K. T., Tomaru, K., Ushiku, S., Ichikawa, Y., Sugimura, Y., Natsuaki, T., Okuda, S., and Teranaka, M. 1994. Characterization of two viruses isolated from patchouli in Japan. Plant Dis. 78:1094-1097.

17. Nevins, J. R. 1983. The pathway of eukaryotic mRNA formation. Ann. Rev. Biochem. 52:441-466.

18. Qi, Y., Zhou, X., and Li, D. 2000. Complete nucleotide sequence and infectious cDNA clone of the RNA1 of a Chinese isolate of Broad bean wilt virus 2. Virus Genes 20:201-207.

19. Ritzenthaler, C., Viry, M., Pinck, M., Margis, R., Fuchs, M., and Pinck, L. 1991. Complete nucleotide sequence and genetic organization of Grapevine fanleaf nepovirus RNA1. J. Gen. Virol. 72:2357-2365.

20. Sambrook, J., Fritsch, E. F., and Maniatis, T. 1989. Electrophoresis of RNA through gels containing formaldehyde. Pages 7.43-7.45 in: Molecular Cloning. N. Ford, C. Nolan, and M. Ferguson, eds. Cold Spring Harbor Laboratory, Cold Spring Harbor, NY.

21. Takeuchi, S., Hikichi, Y., Kawada, Y., and Okuno, T. 2000. Detection of Tobamoviruses from soils by non-precoated indirect ELISA. J. Gen. Plant Pathol. 66:153-158.

22. Taylor, R. H., and Stubbs, L. L. 1972. Broad bean wilt virus. No. 81 in: Descriptions of Plant Viruses. Commonw. Mycol. Inst./Assoc. Appl. Biol., Kew, England.

23. Thompson, J. D., Gibson, T. J., Plewniak, F., Jeanmougin, F., and Higgins, D. G. 1997. The ClustalX windows interface: Flexible strategies for multiple sequence alignment aided by quality analysis tools. Nucleic Acids Res. 24:4876-4882.

24. Uyemoto, J. K., and Provvidenti, R. 1974. Isolation and identification of two serotypes of Broad bean wilt virus. Phytopathology 64:1547-1548.

25. Valverde, R. A., and Fulton, J. P. 1996. Comoviruses: Identification and diseases caused. Pages 17-33 in: The Plant Viruses, volume 5. Polyhedral Virions and Bipartite RNA Genomes. B. D. Harrison and A. F. Murant, eds. Plenum Press, New York.

26. Wellink, J., Le Gall, O., Sanfacon, H., Ikegami, M., and Jones, A. T. 2000 Family Comoviridae. Pages 691-701 in: Virus Taxonomy. Seventh Report of the International Committee on Taxonomy of Viruses. M. H. V. van Regenmortel, C. M. Fauquet, D. H. L. Bishop, E. B. Carstens, M. K. Estes, S. M. Lemon, J. Maniloff, M. A. Mayo, D. J. McGeoch, C. R. Pringle, and R. B. Wickner, eds. Academic Press, New York.

27. Zaret, K. S., and Sherman, F. 1982. DNA sequence required for efficient transcription termination in yeast. Cell 28:563-573. 